\title{
Evaluation of Dietary Glycerin Inclusion during Different Broiler Rearing Phases
}

\section{-Author(s)}

\section{Freitas LW'}

Menten JFM'

Zavarize $\mathrm{KCl}$

Pereira $\mathrm{R}^{\prime}$

Romano GG'

Lima MB'

Dias CTS"

Departamento de Zootecnia, Escola Superior de Agricultura "Luiz de Queiroz", Universidade de São Paulo, Piracicaba, Brasil.

" Departamento de Estatística e Experimentação Agronômica, Escola Superior de Agricultura "Luiz de Queiroz", Universidade de São Paulo, Piracicaba, Brasil.

\section{Mail Address}

Corresponding author e-mail address Kelen C. Zavarize

Avenida Pádua Dias, 11 - Piracicaba - São Paulo, Brazil

13418-900

Tel: $\quad$ (55 19) 996289003

Email: kelen_zavarize@yahoo.com.br

\section{nKeywords}

Alternative feedstuff, biodiesel, broiler litter; nutrition, pododermatitis.

\section{ABSTRACT}

The objective of this study was to evaluate the effect of the dietary addition of different levels of glycerin on the performance, litter moisture, pododermatitis incidence, and carcass and parts yield of broilers. In total, 1,610 broilers were reared in 35 pens with 46 birds each. A completely randomized experimental design, with five treatments with seven replicates was applied. The experimental treatments were: T1: control diet; T2: dietary inclusion of $5 \%$ glycerin from 1-42 days of age; T3: dietary inclusion of $10 \%$ glycerin from 1-42 days of age; T4: dietary inclusion of 5\% glycerin from 7-42 days of age; T5: dietary inclusion of $10 \%$ glycerin from $7-42$ days of age. The diets containing glycerin fed since the pre-starter period improved broiler weight gain and feed conversion ratio, but did not influence feed intake or livability. At the end of the experiment, the production efficiency index of the broilers fed $10 \%$ glycerin during the entire rearing period was significantly reduced compared with the other treatments. Litter moisture in the pens of broilers fed $10 \%$ glycerin during the entire rearing period was higher compared to the other treatments since day 21.Diets containing $10 \%$ glycerin, both for the entire rearing period (1-42 days) or only after the pre-starter phase (7-42 days), influenced broiler performance and incidence of severe pododermatitis, reducing the production efficiency indexes at 42 days. Glycerin may be added up to $5 \%$ in broiler's diets with no effect on performance, litter moisture and carcass yield, indicating that this co-product of the biodiesel industry can be used as an alternative feedstuff for broilers.

\section{INTRODUCTION}

Corn is the main energy source used in poultry feeds. Approximately $80 \%$ of Brazilian corn production is used in the formulation of feeds. Corn accounts for $65-70 \%$ of poultry feed composition. It is a valuable grain also used in human foods, and its replacement in feeds by other energy sources may reduce animal feeding costs.

The use of alternative feedstuffs, particularly in poultry production, may reduce production costs and increase the availability of traditional ingredients for human foods. Among alternative feedstuffs, glycerin is an energy-rich and low-cost ingredient. The glycerin obtained from biodiesel production contains $70-80 \%$ glycerol. Literature reports a wide range of chemical composition and energy values for glycerin. This variation may be due to the lack of purity of the samples because of the methods used for biodiesel production (Zavarize et al., 2014).

The objective of this study was to evaluate the effect of the dietary addition of different levels of glycerin on the performance, litter moisture, pododermatitis incidence, carcass and parts yield of broilers relative to glycerin feeding period. 
Freitas LW, Menten JFM, Zavarize KC, Pereira R, Romano GG, Lima MB, Dias CTS
Evaluation of Dietary Glycerin Inclusion during

Different Broiler Rearing Phases

\section{MATERIAL AND METHODS}

In total, 1,610 Cobb 500 broilers were reared in 35 pens with 46 birds each. A completely randomized experimental design, with five treatments with seven replicates was applied. The experimental treatments were T1: control diet; T2: dietary inclusion of $5 \%$ glycerin from 1-42 days of age; T3: dietary inclusion of 10\% glycerin from 1-42 days of age; T4: dietary inclusion of $5 \%$ glycerin from $7-42$ days of age; T5: dietary inclusion of $10 \%$ glycerin from $7-42$ days of age.

The glycerin product added to the diets contained $83 \%$ glycerol, $0.09 \%$ ether extract, $7 \%$ ashes, and $1.8 \%$ sodium. Glycerin gross energy value was determined in a bomb calorimeter as $3,620 \mathrm{kcal} / \mathrm{kg}$, and the metabolizable energy value (3,258 kcal AMEn/ $\mathrm{kg}$ ) used for feed formulation was calculated as $90 \%$ of the GE value.

The rearing period was divided in four phases: prestarter (1-7 days), starter (7-21 days), grower (21-35 days), and finisher (35-42 days), as the corresponding feeds were formulated to supply the broilers' nutritional requirements proposed by Rostagno et al. (2011), as shown in Tables 1 and 2.

Birds and feed residues were weekly weighed to calculate the live performance parameters (feed intake, weight gain, feed conversion ratio, live weight, livability, and production efficiency index). Production efficiency index was calculated according to the equation: $\mathrm{PEI}=[($ daily weight gain $\mathrm{x}$ livability $) /$ feed conversion ratio] x 100 .

On day 7 , one bird per replicate, with the average body weight of the replicate, was selected, identified, sacrificed by neck dislocation, and immediately frozen at $-18^{\circ} \mathrm{C}$. Carcass samples were freeze-dried for 170 days for subsequent determination of their dry matter content.

Litter moisture percentage was determined on days $21,28,35$, and 42 . Litter samples were collected from three different locations in each pen, distant from the feeder and drinker Litter samples were weighed and

Table 1 - Ingredients and calculated nutritional composition of the pre-starter (1-7 days) and starter (8-21 days) diets.

\begin{tabular}{|c|c|c|c|c|c|c|}
\hline \multirow{3}{*}{ Ingredients } & \multicolumn{4}{|c|}{ Pre-starter } & \multicolumn{2}{|l|}{ Starter } \\
\hline & \multicolumn{6}{|c|}{ Glycerin inclusion (\%) } \\
\hline & 0.0 & 5.0 & 10.0 & 0.0 & 5.0 & 10.0 \\
\hline Ground corn & 48.91 & 42.97 & 37.04 & 53.78 & 47.85 & 41.91 \\
\hline Soybean meal & 43.58 & 44.58 & 45.57 & 38.55 & 39.55 & 40.54 \\
\hline Corn oil & 3.43 & 3.61 & 3.79 & 3.82 & 4.00 & 4.18 \\
\hline Glycerin & 0.00 & 5.00 & 10.00 & 0.00 & 5.00 & 10.00 \\
\hline Dicalcium phosphate & 1.86 & 1.87 & 1.88 & 1.53 & 1.54 & 1.55 \\
\hline Limestone & 0.91 & 0.91 & 0.90 & 0.94 & 0.94 & 0.93 \\
\hline Salt & 0.51 & 0.28 & 0.05 & 0.48 & 0.25 & 0.03 \\
\hline DL-methionine & 0.33 & 0.33 & 0.34 & 0.39 & 0.40 & 0.40 \\
\hline L-lysine $\mathrm{HCl}$ & 0.14 & 0.13 & 0.11 & 0.16 & 0.14 & 0.12 \\
\hline L-threonine & 0.05 & 0.05 & 0.05 & 0.04 & 0.04 & 0.04 \\
\hline Vitamin supplement $^{1}$ & 0.10 & 0.10 & 0.10 & 0.10 & 0.10 & 0.10 \\
\hline Mineral supplement ${ }^{2}$ & 0.05 & 0.05 & 0.05 & 0.05 & 0.05 & 0.05 \\
\hline Choline chloride $60 \%$ & 0.08 & 0.08 & 0.08 & 0.08 & 0.08 & 0.08 \\
\hline Anticoccidial agent ${ }^{3}$ & 0.05 & 0.05 & 0.05 & 0.05 & 0.05 & 0.05 \\
\hline Growth promoter ${ }^{4}$ & 0.005 & 0.005 & 0.005 & 0.005 & 0.005 & 0.005 \\
\hline \multicolumn{7}{|l|}{ Calculated values } \\
\hline $\mathrm{ME}, \mathrm{kcal} / \mathrm{kg}$ & 2.960 & 2.960 & 2.960 & 3.050 & 3.050 & 3.050 \\
\hline$C P, \%$ & 23.92 & 23.89 & 23.86 & 22.07 & 22.05 & 22.02 \\
\hline $\mathrm{Ca}, \%$ & 0.92 & 0.92 & 0.92 & 0.84 & 0.84 & 0.84 \\
\hline Available P, \% & 0.47 & 0.47 & 0.47 & 0.40 & 0.40 & 0.40 \\
\hline $\mathrm{Na}, \%$ & 0.22 & 0.22 & 0.22 & 0.21 & 0.21 & 0.21 \\
\hline Digestible methionine, \% & 0.63 & 0.63 & 0.64 & 0.67 & 0.67 & 0.68 \\
\hline Digestible Met + Cys, \% & 0.95 & 0.95 & 0.95 & 0.97 & 0.97 & 0.98 \\
\hline Digestible lysine, \% & 1.32 & 1.32 & 1.32 & 1.22 & 1.22 & 1.22 \\
\hline Digestible threonine, \% & 0.86 & 0.86 & 0.86 & 0.79 & 0.79 & 0.79 \\
\hline Electrolyte balance, mEq/kg & 236 & 234 & 232 & 216 & 214 & 212 \\
\hline
\end{tabular}

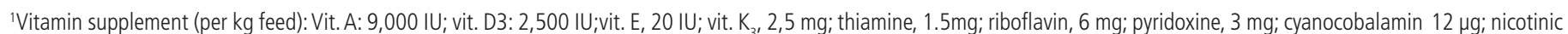
acid, 25 mg; pantothenic acid, 12 mg; biotin, 0.06 mg; folic acid, 0.8 mg; selenium, 0.25 mg. ${ }^{2}$ Mineral supplement (per kg feed):I, 1 mg; Fe, 50 mg; Cu, 10 mg; Co, 1 mg; Mn, 75 mg; Zn, 50 mg. ${ }^{3}$ Coxistac: $12 \%$ salinomycin. ${ }^{4}$ Halquinol BP 80: 60\% chlorohydroxyquinoline. 
Freitas LW, Menten JFM,

Zavarize KC, Pereira $\mathbf{R}$,

Romano GG, Lima MB, Dias CTS
Evaluation of Dietary Glycerin Inclusion during

Different Broiler Rearing Phases

Table 2 - Ingredients and calculated nutritional composition of the grower (22-35 days) and finisher (36-42 days) diets.

\begin{tabular}{|c|c|c|c|c|c|c|}
\hline \multirow{3}{*}{ Ingredients } & \multicolumn{4}{|c|}{ Grower } & \multicolumn{2}{|l|}{ Finisher } \\
\hline & \multicolumn{6}{|c|}{ Glycerin inclusion (\%) } \\
\hline & 0.0 & 5.0 & 10.0 & 0.0 & 5.0 & 10.0 \\
\hline Ground corn & 56.53 & 50.60 & 44.66 & 60.46 & 54.53 & 48.57 \\
\hline Soybean meal & 35.30 & 36.30 & 37.29 & 31.85 & 32.85 & 33.84 \\
\hline Corn oil & 4.82 & 5.00 & 5.17 & 4.77 & 4.95 & 5.13 \\
\hline Glycerin & 0.00 & 5.00 & 10.00 & 0.00 & 5.00 & 10.00 \\
\hline Dicalcium phosphate & 1.31 & 1.32 & 1.33 & 1.10 & 1.10 & 1.11 \\
\hline Limestone & 0.89 & 0.88 & 0.88 & 0.80 & 0.80 & 0.78 \\
\hline Salt & 0.46 & 0.23 & 0.00 & 0.45 & 0.22 & 0.00 \\
\hline DL-methionine & 0.27 & 0.27 & 0.28 & 0.24 & 0.25 & 0.26 \\
\hline L-lysine $\mathrm{HCl}$ & 0.15 & 0.13 & 0.11 & 0.16 & 0.15 & 0.13 \\
\hline L-threonine & 0.03 & 0.03 & 0.03 & 0.03 & 0.03 & 0.03 \\
\hline Vitamin supplement ${ }^{1}$ & 0.08 & 0.08 & 0.08 & 0.06 & 0.06 & 0.06 \\
\hline Mineral supplement ${ }^{2}$ & 0.05 & 0.05 & 0.05 & 0.05 & 0.05 & 0.05 \\
\hline Choline chloride $60 \%$ & 0.06 & 0.06 & 0.06 & 0.04 & 0.04 & 0.04 \\
\hline Anticoccidial agent ${ }^{3}$ & 0.05 & 0.05 & 0.05 & & & \\
\hline Growth promoter ${ }^{4}$ & 0.005 & 0.005 & 0.005 & & & \\
\hline \multicolumn{7}{|l|}{ Calculated values } \\
\hline \multicolumn{7}{|l|}{$\mathrm{ME}, \mathrm{kcal} / \mathrm{kg}$} \\
\hline$C P, \%$ & 3.150 & 3.150 & 3.150 & 3.200 & 3.200 & 3.200 \\
\hline $\mathrm{Ca}, \%$ & 20.74 & 20.71 & 20.68 & 19.49 & 19.46 & 19.42 \\
\hline Available P, \% & 0.76 & 0.76 & 0.76 & 0.66 & 0.66 & 0.66 \\
\hline $\mathrm{Na}, \%$ & 0.35 & 0.35 & 0.35 & 0.31 & 0.31 & 0.31 \\
\hline Digestible methionine, \% & 0.20 & 0.20 & 0.20 & 0.19 & 0.19 & 0.20 \\
\hline Digestible Met + Cys, \% & 0.54 & 0.54 & 0.54 & 0.51 & 0.51 & 0.51 \\
\hline Digestible lysine, \% & 0.83 & 0.83 & 0.83 & 0.77 & 0.77 & 0.77 \\
\hline Digestible threonine, \% & 1.13 & 1.13 & 1.13 & 1.06 & 1.06 & 1.06 \\
\hline \multirow[t]{2}{*}{ Electrolyte balance, mEq/kg } & 0.74 & 0.74 & 0.74 & 0.69 & 0.69 & 0.69 \\
\hline & 202 & 200 & 198 & 189 & 187 & 185 \\
\hline
\end{tabular}

'Vitamin supplement (per kg feed):vit. A, 9,000 IU; vit. D, $2,500 \mathrm{IU}$; vit. E, $20 \mathrm{IU}$; vit. K, $2.5 \mathrm{mg}$; thiamine, $1.5 \mathrm{mg}$; riboflavin, $6 \mathrm{mg}$; pyridoxine, 3 mg; cyanocobalamin $12 \mu$; nicotinic acid, $25 \mathrm{mg}$; pantothenic acid, 12mg; biotin, $0.0 .06 \mathrm{mg}$; folic acid, $0.8 \mathrm{mg}$; selenium, $0.25 \mathrm{mg}{ }^{2}{ }^{2}$ Mineral supplement (per kg feed):I, $1 \mathrm{mg} ; \mathrm{Fe}, 50 \mathrm{mg} ; \mathrm{Cu}, 10 \mathrm{mg} ; \mathrm{Co}, 1 \mathrm{mg} ; \mathrm{Mn}, 75 \mathrm{mg}$; Zn, 50 mg. ${ }^{3}$ Coxistac: $12 \%$ salinomycin. ${ }^{4}$ Halquinol BP 80: 60\% chlorohydroxyquinoline.

dried in a forced-ventilation oven $\left(55^{\circ} \mathrm{C}\right.$ for 72 hours), and weighed again.

On day 42 , four birds per replicate were scored for pododermatitis according to a 0-1 scale as: 0 (no lesions), 1 (lesion covering up to $50 \%$ of the footpad surface), and 2 (lesion covering more than $50 \%$ of the footpad surface).

On day 48, all birds were fasted for eight hours, weighed, and sacrificed to determine carcass, parts, and abdominal fat yields. Birds were sacrificed by electrical stunning and bled. After evisceration and removal of the abdominal fat, carcasses were not placed in the chiller. Carcasses with no feet, head, neck, and offal were weighed to calculate their yield as a percentage of live weight. Carcasses were then cut up according to industrial processing methods into breast, legs (thighs and drumsticks), back, and wings; and their yields were calculated as a percentage of carcass weight. Feet, head + neck, and abdominal fat (removed from the abdominal cavity and from the gizzard) yields were calculated as a percentage of live weight.

The results obtained for performance parameters, carcass dry matter content, and carcass traits were submitted to analysis of variance using the PROC GLM of SAS statistical package version 9.2. When significant effects $(p<0.05)$ were detected, means were compared by the test of Tukey at $5 \%$ significance level.

Pododermatitis scores were analyzed by the PROC FREQ of SAS statistical package version 9.2, and treatment means were compared by the test of Kruskal-Wallis $(p<0.05)$. When significant effects were determined, means were submitted to the Chi-square test $\left(\chi^{2}\right)$.

\section{RESULTS AND DISCUSSION}

Table 3 presents the performance results obtained. The statistical analyses showed that the diet with the inclusion of $5 \%$ glycerin promoted significantly better 
Table 3 - Performance parameters measured in the periods of 1-7, 1-21, and 1-42 days of the rearing period of broilers fed with glycerin.

\begin{tabular}{|c|c|c|c|c|c|c|c|}
\hline \multirow{2}{*}{ Parameters } & \multicolumn{5}{|c|}{ Treatments $^{1}$} & \multirow{2}{*}{$p$ value } & \multirow{2}{*}{$\mathrm{CV}^{8}(\%)$} \\
\hline & $\mathrm{T} 1$ & $\mathrm{~T} 2$ & T3 & T4 & T5 & & \\
\hline \multicolumn{8}{|l|}{ 1-7 days } \\
\hline $\mathrm{BW}^{2}, \mathrm{~g}$ & $204^{b}$ & $212^{a}$ & $209^{a b}$ & - & - & 0.0014 & 2.03 \\
\hline$W G^{3}, g$ & $158^{b}$ & $166^{a}$ & $163^{a}$ & - & - & 0.0007 & 2.49 \\
\hline $\mathrm{Fl}^{4}, \mathrm{~g}$ & 167 & 170 & 169 & - & - & 0.5456 & 2.69 \\
\hline $\mathrm{FCR}^{5}$ & $1.059^{b}$ & $1.022^{\mathrm{a}}$ & $1.035^{\mathrm{ab}}$ & - & - & 0.0059 & 2.25 \\
\hline$L^{6}, \%$ & 99.4 & 99.5 & 98.9 & - & - & 0.3752 & 1.18 \\
\hline Carcass DM, \% & 39.84 & 37.12 & 36.58 & - & - & 0.3058 & 10.87 \\
\hline \multicolumn{8}{|l|}{ 1- 21 days } \\
\hline $\mathrm{BW}^{2}, \mathrm{~g}$ & 1116 & 1142 & 1106 & 1116 & 1126 & 0.0996 & 2.2 \\
\hline$W G^{3}, g$ & 1069 & 1096 & 1059 & 1069 & 1080 & 0.0935 & 2.28 \\
\hline $\mathrm{Fl}^{4}, \mathrm{~g}$ & $1484^{\mathrm{ab}}$ & $1481^{\mathrm{ab}}$ & $1513^{a}$ & $1448^{b}$ & $1438^{b}$ & 0.0034 & 2.42 \\
\hline $\mathrm{FCR}^{5}$ & $1.388^{\mathrm{ab}}$ & $1.352^{\mathrm{a}}$ & $1.428^{b}$ & $1.345^{a}$ & $1.341^{\mathrm{a}}$ & $<0.0001$ & 2.44 \\
\hline$L^{6}, \%$ & $96.9^{\mathrm{ab}}$ & $97.8^{a}$ & $91.6^{\mathrm{b}}$ & $96.9^{a b}$ & $96.3^{\mathrm{ab}}$ & 0.0184 & 3.63 \\
\hline \multicolumn{8}{|l|}{ 1-42days } \\
\hline $\mathrm{BW}^{2}, \mathrm{~g}$ & 3218 & 3280 & 3211 & 3278 & 3277 & 0.4892 & 2.88 \\
\hline$W G^{3}, g$ & 3172 & 3234 & 3165 & 3232 & 3231 & 0.4857 & 2.92 \\
\hline $\mathrm{Fl}^{4}, \mathrm{~g}$ & 5177 & 5279 & 5272 & 5274 & 5299 & 0.6006 & 2.68 \\
\hline $\mathrm{FCR}^{5}$ & 1.634 & 1.632 & 1.666 & 1.632 & 1.64 & 0.349 & 2.02 \\
\hline$L^{6}, \%$ & 89.9 & 87.6 & 79.7 & 90.10 & 86.0 & 0.058 & 7.52 \\
\hline $\mathrm{PEI}^{7}$ & $417^{a}$ & $413^{a}$ & $363^{b}$ & $425^{a}$ & $403^{a b}$ & 0.0111 & 7.45 \\
\hline
\end{tabular}

${ }^{1}$ Treatments: T1 - control diet (no glycerin inclusion); T2 - diet with 5\% glycerin inclusion from 1-42 days; T3 -diet with 10\% glycerin inclusion from 1-42 days; T4 - diet with 5\% glycerin inclusion from 7-42 days; and T5 - diet with 10\% glycerin inclusion from 7-42 days. ${ }^{2} \mathrm{BW}$ :body weight on day $42 .{ }^{3} \mathrm{WG}$ : weight gain. ${ }^{4} \mathrm{Fl}$ :feed intake. ${ }^{5} \mathrm{FCR}:$ feed conversion rati $0 .{ }^{6} \mathrm{~L}:$ Livability. ${ }^{7} \mathrm{PEl}$ :production efficiency index. ${ }^{8} \mathrm{CV}$ :coefficient of variation. ${ }^{9} \mathrm{Carcass}$ dry matter:Carcass dry matter after freeze-drying. ${ }^{\mathrm{a} b \mathrm{~b}}$ Means in the same row followed by different superscripts are different by the test of Tukey $(p<0.05)$.

performance $(p<0.05)$ until broilers were 21 days old, in agreement with the findings of Bernardino et al. (2014), Zavarizeet al.(2012), Silva et al. (2012), and Dourado et al. (2010). In addition, consistent with studies evaluating the addition of increasing glycerin levels (up to 10\%) in broiler diets (Zavarize et al., 2012; Menten et al., 2008; Fernandes et al., 2010), no negative effect of the inclusion of up to $8 \%$ of glycerin was detected on broiler performance, suggesting that glycerin can be included in broiler diets, provided its chemical composition. Mandalawi et al. 2014 showed that raw glycerin from the biodiesel industry can be used efficiently, up to $10 \%$ of the diet, as a source of energy for broilers from 1 to 21 days of age and that the energy content of well-processed raw glycerin depends primarily on its glycerol content. However, when high glycerin levels were added to the diet (20 and 25\%), Simon et al. (1997) performance impairment was observed. Guerra et al. (2011) obtained worse feed conversion ratios due to high feed intake when broilers were fed a diet with $10 \%$ glycerin relative to lower levels of glycerin inclusion. On the other hand, Cerrate et al. (2006) obtained lower feed intake in broilers fed diets of $10 \%$ of glycerin compared with $5 \%$, and attributed this result to the reduced flow of the feed in the feeders, which consequently limited feed intake.

Whole carcass dry matter content of the broilers sacrificed with seven days of age are shown in Table 3.There was no effect of dietary glycerin inclusion ( $p>0.05$ ) on whole carcass dry matter content of broilers sacrificed with seven days of age. Previous studies indicated that the inclusion of high glycerin levels in starter broiler diets increased weight gain during the first days of rearing; however, when fed during the entire rearing period, performance losses were observed (Simon et al., 1997; Cerrate et al, 2006; Silva et al., 2012). This result suggests that the use of glycerin does not promote water retention in the carcass, but true weight gain.

Carcass trait results are shown in Table 4. The was no effect of the treatments $(p>0.05)$ on carcass and parts yield. These results are consistent with the findings of Guerra et al. (2011), Silva et al. (2012), and Gianfelici (2009), using a maximum level of $10 \%$ of glycerin in broiler diets. This indicates that glycerin can be added up to this level in the diet with no adverse effects on carcass yield or commercial parts yields. However, Cerrate et al. (2006) observed that broilers fed diets containing 2.5 and $5 \%$ of glycerin, presented 
Table 4 - Carcass and parts yields of 49-d-old broilers fed with different glycerin levels.

\begin{tabular}{llllllll}
\hline Treatments $^{2}$ & $\mathrm{BW}^{2}, \mathrm{~g}$ & $\mathrm{CY}^{3}, \%$ & $\mathrm{BrY}^{4}, \%$ & $\mathrm{WY}, \%$ & $\mathrm{LY}, \%$ & $\mathrm{BY}^{7}, \%$ & $\mathrm{AF}^{8}, \%$ \\
\hline T1 & 3872 & 72.34 & 42.39 & 10.23 & 32.66 & 14.12 & 1.32 \\
T2 & 3931 & 72.11 & 42.95 & 10.00 & 32.35 & 14.40 & 1.48 \\
T3 & 3889 & 72.15 & 42.78 & 10.16 & 32.27 & 14.48 & 1.43 \\
T4 & 4150 & 72.65 & 43.75 & 9.80 & 31.92 & 14.17 & 1.29 \\
T5 & 4001 & 72.72 & 43.62 & 10.21 & 31.65 & 14.35 & 1.40 \\
\hline p value & & 0.4091 & 0.1875 & 0.1798 & 0.2873 & 0.5307 & 0.6896 \\
CV $(\%)$ & & 1.76 & 4.87 & 6.49 & 4.95 & 5.49 & 33.85 \\
\hline
\end{tabular}

'Treatments: T1 - control diet (no glycerin inclusion); T2 - diet with 5\% glycerin inclusion from 1-42 days; T3 -diet with 10\% glycerin inclusion from 1-42 days; T4 - diet with 5\% glycerin inclusion from 7-42 days; and T5 - diet with $10 \%$ glycerin inclusion from 7-42 days. ${ }^{2} \mathrm{BW}$ :body weight on day $48 ;{ }^{3} \mathrm{CY}$ :carcass yield; ${ }^{\mathrm{B} B r Y}$ :breast yield; ${ }^{5} \mathrm{WY}$ :wing yield; ${ }^{6} \mathrm{LY}$ :leg yield; ${ }^{7 B Y}$ :back yield; ${ }^{8} \mathrm{AF}$ :abdominal fat; ${ }^{9} \mathrm{CV}$ :coefficient of variation.

higher carcass and breast yields compared with those fed a standard diet.

Litter moisture results are shown in Table 5. The litter of the broilers fed the diet with $10 \%$ of glycerin during the entire rearing period (1-42 days) presented higher moisture levels $(p<0.05)$ after day 21 , compared with the other treatments. Freitas et al. (2011) and Guerra et al. (2011), evaluating the inclusion of increasing glycerin level in broiler diets, also observed higher litter moisture after day 21, when the diets contained more than $10 \%$ of glycerin. Bernadino et al. (2014) found increased litter moisture when broilers were fed $7 \%$ of glycerin in the diet according to Robinson \& Newsholme (1969), the digestion of glycerol, present in glycerin, is limited by the saturation of the enzyme glycerol kinase. In addition, glycerol is a highly hygroscopic molecule,

Table 5 - Litter moisture levels on days 21, 28, 35, and 42, according to experimental treatment.

\begin{tabular}{lcccc}
\hline Treatments $^{1}$ & 21 days & 28 days & 35 days & 42 days \\
\hline T1 & $29.62^{\mathrm{b}}$ & $32.73^{\mathrm{b}}$ & $34.66^{\mathrm{bc}}$ & $40.90^{\mathrm{ab}}$ \\
T2 & $34.17^{\mathrm{ab}}$ & $35.30^{\mathrm{b}}$ & $40.63^{\mathrm{ab}}$ & $46.26^{\mathrm{a}}$ \\
T3 & $37.50^{\mathrm{a}}$ & $44.14^{\mathrm{a}}$ & $47.83^{\mathrm{a}}$ & $47.70^{\mathrm{a}}$ \\
T4 & $29.43^{\mathrm{b}}$ & $30.90^{\mathrm{b}}$ & $30.29^{\mathrm{c}}$ & $40.82^{\mathrm{b}}$ \\
T5 & $30.56^{\mathrm{b}}$ & $32.50^{\mathrm{b}}$ & $35.20^{\mathrm{bc}}$ & $37.10^{\mathrm{b}}$ \\
\hline Valor de P & $<0.0001$ & $<0.0001$ & $<0.0001$ & 0.0032 \\
CV $(\%)$ & 9.69 & 11.15 & 13.19 & 12.06 \\
\hline
\end{tabular}

${ }^{1}$ Treatments: T1 - control diet (no glycerin inclusion); T2 - diet with 5\% glycerin inclusion from 1-42 days; T3 -diet with 10\% glycerin inclusion from 1-42 days; T4 - diet with 5\% glycerin inclusion from 7-42 days; and T5 - diet with $10 \%$ glycerin inclusion from 7-42 days. ${ }^{2} \mathrm{CV}$ : coefficient of variation. ${ }^{\text {ab, }, \mathrm{c}}$ Means in the same column followed by different superscripts are different by the test of Tukey $(p<0.05)$.

carrying water during its excretion. Gianfelici (2009) and Romano et al. (2014) observed that levels higher than $7.5 \%$ of glycerin in broiler diets increased water consumption and excretion, which may have adverse effects on the field due to higher litter moisture. Glycerin is a low molecular weight hydrophilic compound, which is easily excreted by the kidneys.
Silva et al. (2012) described a positive linear effect of dietary glycerin levels on litter moisture evaluated when broilers were 43 days old, and observed higher excreta moisture after the third week of rearing in broilers fed $10 \%$ of glycerin.

The incidence of pododermatitis observed in the present study is shown in Table 6. The incidence of

Table 6 - Incidence and severity (score) of pododermatitis in the right footpad (RF) and left footpad (LF) of broilers fed with different glycerin levels at 42 days.

\begin{tabular}{|c|c|c|c|c|c|c|}
\hline & \multirow[b]{2}{*}{ Score } & \multicolumn{5}{|c|}{ Treatments $^{1}$} \\
\hline & & T1 & $\mathrm{T} 2$ & T3 & T4 & T5 \\
\hline \multirow{3}{*}{ RF (\%) } & 0 & $51.43^{a}$ & $5.72^{b}$ & $2.86^{b}$ & $20.00 \mathrm{ab}$ & $31.42^{\mathrm{ab}}$ \\
\hline & 1 & 31.43 & 28.57 & 17.14 & 34.29 & 14.29 \\
\hline & 2 & $17.14^{b}$ & $65.71^{a}$ & $80.00^{a}$ & $45.71 \mathrm{ab}$ & $54.29 \mathrm{ab}$ \\
\hline \multirow{3}{*}{$\begin{array}{l}\text { LF } \\
(\%)\end{array}$} & 0 & $51.43^{a}$ & $5.72 \mathrm{ab}$ & $0.00^{b}$ & $17.14 \mathrm{ab}$ & $28.57 \mathrm{ab}$ \\
\hline & 1 & 31.43 & 25.71 & 14.29 & 28.57 & 25.72 \\
\hline & 2 & $17.14^{b}$ & $68.57^{a}$ & $85.71^{a}$ & 54.29 ab & $45.71 \mathrm{ab}$ \\
\hline
\end{tabular}

'Treatments: T1 - control diet (no glycerin inclusion); T2 - diet with 5\% glycerin inclusion from 1-42 days; T3 -diet with 10\% glycerin inclusion from 1-42 days; T4 - diet with $5 \%$ glycerin inclusion from 7-42 days; and T5 - diet with $10 \%$ glycerin inclusion from 7-42 days. ${ }^{a, b}$ Means in the same row followed by different superscripts are different by the test of Tukey $(p<0.05)$. 
Freitas LW, Menten JFM,

Zavarize KC, Pereira $R$,

Romano GG, Lima MB, Dias CTS
Evaluation of Dietary Glycerin Inclusion during

Different Broiler Rearing Phases pododermatitis was significantly higher $(p<0.05)$ when birds were fed glycerin during the entire experimental period (1-42 days), and all birds fed $10 \%$ of glycerin were affected.

The incidence of severe pododermatitis (score 2) was only $17 \%$ in the broilers not fed glycerin, whereas more than $45 \%$ of those fed diets containing glycerin during the entire rearing period (1-42 days) presented score 2 . This result may be attributed to the high litter moisture in the pens of the latter, which was higher than $25 \%$, which is the highest recommended values (UBA, 2008).

Litter moisture may greatly influence the incidence and the severity of pododermatitis (Traldi et al., 2007). Bernardi (2011) indicated that high excreta output increase litter moisture and nitrogen content, also increasing the incidence and severity of footpad lesions.

\section{CONCLUSIONS}

Diets containing $10 \%$ of glycerin, both for the entire rearing period (1-42 days) or only after the pre-starter phase (7-42 days), influence broiler performance and incidence of severe pododermatitis, reducing the production efficiency index at 42 days.

Glycerin may be added up to $5 \%$ in broiler's diets with no effect on performance; litter moisture and carcass yield, indicating that this co-product of the biodiesel industry can be used as an alternative feedstuff for broilers.

\section{REFERENCES}

Bernardi R. Problemas locomotores em frangos de corte [dissertation]. Dourados (MS): Universidade Federal da Grande Dourados; 2011.

Bernardino VMP, Rodrigues PB, Oliveira DH, Freitas RTF, Naves LP, Nardelli NBS, et al. Fontes e níveis de glicerina para frangos de corte no período de 8 a 21 dias de idade. Revista Brasileira de Saúde Produção Animal 2014;15(3):649-658.

Cerrate SE, Yan F, Wang Z, Coto C, Sacakli P, Waldroup PW. Evaluation of glycerin from biodiesel production as a feed ingredient for broilers. International Journal of Poultry Science 2006;5(11):1001-1007.

Dourado LRB, Barbosa FC, Bezerra GC, Silva FF, Santos ET, Lima SPB, et al. Glicerina em dietas para frangos de corte de 1 a 8 dias. Anais do $4^{\circ}$ Congresso Latino Americano de Nutrição Animal; 2010; São Pedro, São Paulo. Brasil. p. 23-24
Fernandes ML, Barbosa FC, Santos ET, Silva FF, Dourado RLB, Farias LA. Glicerina na alimentação de frangos de corte de 1 a 8 dias de idade criadas em baterias metálicas. Anais da $49^{\circ}$ Reunião Anual da Sociedade Brasileira de Zootecnia; 2012; Brasília, DF. Brasil. p.1-3.

Freitas LW, Zavarize KC, Menten JMF, Pereira R, Lima MB, Silva CLS Qualidade da cama de frangos alimentados com níveis crescentes de glicerina. Conferência APINCO de Ciência e Tecnologia Avícolas; 2011; Santos, São Paulo. Brasil. Campinas: FACTA; 2011. p.1

Gianfelici M.F. Uso de glicerol como fonte de energia para frangos de corte [dissertação]. Porto Alegre (RS): Universidade Federal do Rio Grande do Sul; 2009

Guerra RLH, Murakami AE,Garcia AFQM, Urgnani JF, Moreira I, Picoli KP. Glicerina bruta mista na alimentação de frangos de corte (1 a 42 dias). Revista Brasileira de Saúde e Produção Animal 2011;12(4):1038-1050.

Mandalawi HA, Kimiaeitalab MV, Obregon V, Menoyo D, Mateos GG. Poultry Science 2014;93(11):2855-2863

Menten JFM, Pereira PWZ, Racanicci AMC. Avaliação da glicerina proveniente do biodiesel como ingrediente para rações de frangos de corte. Conferência APINCO de Ciência e Tecnologia Avícolas; 2008; Santos, São Paulo. Brasil. Campinas: FACTA; 2008. p.66.

Robinson J, Newsholme A. The effects of dietary conditions and glycero concentration on glycerol uptake by rat liver and kidney-cortex slices. Journal of Biochemistry 1969;112(4):449-453.

Romano GG, Menten JFM, Freitas LW, Lima MB, Pereira R, Zavarize KC, et al. Effects of glycerol on the metabolism of broilers fed increasing glycerin levels. Revista Brasileira de Ciência Avícola 2014;16(1):97-105.

Rostagno HS, Albino LFT, Donzele JL, Gomes PC, Oliveira RF, Lopes DC, et al. Tables brasileiras para aves e suínos - composição de alimentos e exigências nutricionais. 3rd ed. Viçosa, MG: UFV; 2011.

Silva CLS, Menten JFM, Traldi AB, Pereira R, Zavarize KC, Santarosa J. Glycerin derived from biodiesel production as a feedstuff for broiler diets. Revista Brasileira de Ciência Avícola 2012;14(3):193-202

Simon A, Schwabe M, Bergner $H$. Glycerol supplementation in broiler rations with low crude protein content. Archives of Animal Nutrition $1997 ; 50(3): 271-282$.

Traldi COM, Duarte KF, Moraes VM. Avaliação de probióticos na dieta de frangos de corte criados em cama nova ou reutilizada. Revista Brasileira de Zootecnia 2007;36(3):660-665.

União Brasileira de Avicultura. Protocolo de boas práticas de produção de frangos de corte. São Paulo; 2008.

Zavarize KC. Utilização de glicerina proveniente da produção de biodiesel na dieta de frangos de corte [tese]. Piracicaba (SP): Universidade de São Paulo; 2012

Zavarize KC, Menten JFM, Pereira R, Freitas LW, Romano GG, Bernardino $M$, et al. Metabolizable energy of different glycerin sources derived from national biodiesel production for broilers. Revista Brasileira de Ciência Avícola 2014:16(4):411-416. 